\section{Aa@}

AUTOBIOGRAFIA nr 2 (9) 2017 s. 167-178

ISSN 2353-8694

DOI: $10.18276 / a u \cdot 2017.2 .9-14$

ROZMOWA

\title{
Poznań Edwarda Balcerzana
}

\author{
Rozmawia Beata Małgorzata Wolska
}

Beata Małgorzata Wolska: Wyjechał pan ze Szczecina do Poznania, żeby rozpocząć studia na tamtejszej filologii polskiej. Wspomniał pan już, że trudniej oswajało się stolicę Wielkopolski niż miasto portowe. Proszę to rozwinąć. W jaki sposób jawił się Poznań na tle Szczecina? Czy nad Wartą czuł się pan jak kolonizator wracający na stary kontynent?

Edward Balcerzan: Niestety, muszę zaprzeczyć tej transkontynentalnej metaforze. I Szczecin, i Poznań były dla mnie nowymi przestrzeniami. W rok po wojnie ja, dziecko wojny, nie mogłem traktować Szczecina jako ziemi kolonizowanej. Przybywałem wraz ze zwycięzcami, ale to wcale nie znaczy, że zwycięzca zawsze staje się konkwistatorem. Nawiasem mówiąc, takie poczucie byłoby sprzeczne z moimi chłopięcymi ideałami. Czytając zachłannie powieści „indiańskie”, sercem byłem po stronie współplemieńców Winnetou, nie Bladych Twarzy. Gdy zamieszkałem w Szczecinie, uważałem się za drobinę wielomilionowej społeczności, odzyskującej zagrożone przez Niemców prawo do życia, a wraz z nim utraconą własność, która - cóż, że dawno? - przez wiele wieków, bodaj przez ponad dwadzieścia, należała do ludów zachodniosłowiańskich, łużyckich, lechickich, a następnie wchodziła w skład Polski Piastów, Mieszka I, Bolesława Chrobrego, Bolesława Krzywoustego. Słyszę dziś, że to propaganda władzy powojennej, wspieranej w tym względzie przez Kościół katolicki, wykreowała mit Ziem Odzyskanych. Otóż do mnie przemawiała nie propaganda, lecz architektura mojej codziennej trasy uczniowskiej, która - przez osiem lat! - dawała mi pewność, że przebywam nie na obczyźnie, lecz u siebie: ruiny Zamku Książąt Pomorskich, jego mroczne tunele i prastare mury, miejsca naszych niebezpiecznych zabaw, bitew „na półcegłówy”, próbnych wybuchów prochu, wysypywanego z łusek pocisków karabinowych, znajdowały się tuż obok mojej szkoły. 
No a Poznań? Podjęcia studiów w stolicy Wielkopolski nie da się porównać do powrotu na Stary Kontynent, ponieważ moim „starym kontynentem” było pogranicze Ukrainy i Rosji. Jeżeli miałbym się rozpoznać w metaforze transkontynentalnej, powiedziałbym, że to Polska, cała, od Szczecina po Lublin, stanowiła dla mnie nowy ląd. Lub może raczej: nowy archipelag, zdobywany fragmentami, jak w powieściach przygodowych, niesłychanie zróżnicowany. Gdy przypominam sobie, jeszcze z czasów szkolnych, szaloną, roztańczoną Warszawę w dniu, a właściwie w przedostatniej nocy Festiwalu Młodzieży i Studentów, przerażające baraki niemieckiego obozu koncentracyjnego Majdanek, monumentalny zamek nieopodal Jeleniej Góry, kostiumowy, „góralski” Poznań, zamknięty w operowym wnętrzu, rozbrzmiewającym ariami z „Halki” Stanisława Moniuszki, mam wrażenie, że tak bardzo odmienne, tak osobne „wyspy” krajobrazu Polski powojennej układały mi się właśnie w archipelag, zaskakujący bezustannie swą innością.

Helena Raszka, której nie udało się osiedlić na stałe w Poznaniu, wierzyła święcie, że Poznań ją odtrącił. Jak widać, bohaterami melodramatu mogą być nie tylko ludzie, ale ludzie i miasta. Nigdy nie wtajemniczyła mnie w szczegóły tej smutnej historii, mam nadzieję, że ktoś, kto napisze biografię tej wybitnej poetki, wyjaśni zagadkę. I ja się bałem odtrącenia przez miasto dumne, uniwersyteckie, obyczajowo ukształtowane, posługujące się dziwną odmianą polszczyzny („jak jem dali, a nom zabrali”), tajemniczą leksyką („bimba”, czyli tramwaj, „szkieł”, czyli milicjant), osobliwą wymową niektórych spółgłosek („trzysta trzydzieści trzy” wymawiane jak „czysta czydzieści czy”), nieoczekiwanymi intonacjami (w pytaniu „która jest godzina?” akcent padał nie na „która”, lecz na „jest”). I zostałbym odtrącony niechybnie, bez metafizycznego akompaniamentu, gdybym zawalił egzaminy wstępne na poznańską polonistykę. Nie zawaliłem. Ale początki były trudne. Żeby miasto pokochać, i to na pięć lat, bo tyle miały trwać studia, trzeba w nim zamieszkać. Nie przyznano mi ani miejsca w akademiku, ani stypendium. Jadąc z walizeczką do Poznania, wiozłem od naszej znajomej list polecający do obcej rodziny, zajmującej nieduże mieszkanie w kamienicy na Jeżycach - kłopot w tym, że mój przyjazd nie został uzgodniony listownie... Gdy zjawiliśmy się tam, moja mama i ja, nie zastaliśmy właścicielki, jedynie dwie jej córki, robotnice fabryczne, starsze ode mnie, mocno ze sobą skłócone, które bez emocji przyjęły do wiadomości cichutkiego sublokatora i wskazały mi wolne łóżko w pokoju przechodnim. Późnym wieczorem przyszła pani domu. Zmęczona. Poinformowałem ją, że... ja tu mieszkam! - Ach, tak? - Zerknęła na list, nawet go nie przeczytała, westchnęła „no tak”, zaproponowała niewygórowaną cenę. W czasach szczecińskich miałem dla siebie samodzielny pokój, sam decydowałem o jego wyglądzie, kolorze ścian, czasie pisania, czytania, sprzątania, o zaciemnianiu okien do wywoływania zdjęć i tak dalej. Teraz było łóżko, pod łóżkiem walizka z książkami i bielizną, dwa wieszaki 
na ubrania w szafie, prawo do parzenia herbaty w kuchni, no i wstęp do łazienki. Gdy wykręciłem się przed zabawą taneczną (choreografia nie należała do moich mocnych stron), siostry przestały się do mnie odzywać, a ja korzystałem z jeżyckiego lokum jak z noclegowni.

Od rana do późnych godzin wieczornych próbowałem mieszkać poza mieszkaniem. W mieście - otwartym jak Petersburg z powieści polifonicznej Dostojewskiego (wedle koncepcji Michaiła Bachtina), w mieście ludnym, hałaśliwym, uczelnianym, bibliotecznym, klubowym, stołówkowym, kawiarnianym, kinowym, teatralnym, ulicznym, podmiejskim... czasem dworcowym, czasem tramwajowym... Taki Poznań zaczynałem lubić, może nawet kochać. Zauważyłem, że chętniej się uczę w miejscach gwarnych niż cichych, wiersze pisze mi się lepiej w kawiarni niż w czytelni. I nagle moja „jeżyciada” się urwała. Udało mi się zdobyć miejsce w domu studenckim na Winogradach. Miejsce, czyli nadal łóżko, do tego piętrowe, szafkę, a w pokoju, zwanym izbą, gadał, śmiał się, hałasował, wkuwał słówka, wylegiwał się wesoły tłumek, bodaj ośmioosobowy. Obiektywnie miałem gorzej, subiektywnie lepiej.

B.M.W.: Lepiej?

E.B.: Bo tak samo, jak inni. My, zbieranina z różnych stron Polski, przeżywaliśmy podobne problemy. Nowi nauczyciele, ezoteryczne języki, trudne podręczniki, bezsenne noce przed egzaminami, obśmiewane studium wojskowe, podróże do rodzin, skromne wyżywienie, marne ciuchy, chłopięce mitologie i fantazje dotyczące płci przeciwnej... Anna Wierzbicka zdefiniowała kiedyś wyraz „ludzie” jako „istoty takie, jak my”. Zamieszkałem wśród ludzi takich, jak ja. Czułem się bezpieczny. Zero konfliktów. No może nie zero. Gdy powiesiłem na ścianie portrecik (brodatego) Fiodora Dostojewskiego, któryś z kolegów zapytał, co to za święty. Wyjaśniłem, że rosyjski pisarz. - Rusek? - zapytał ze zgrozą. - Pisarz światowej klasy - powiedziałem twardo. - O kur... - Dodam, że akademik na Winogradach zamieszkiwali nie poloniści, lecz germaniści i historycy. Przydały się moje amatorskie doświadczenia plastyczne. Zbliżały się wiosenne juwenalia. Wypadało przywdziać zabawne kostiumy, tylko skąd je wziąć? Mamy, ciocie czy babcie daleko, nikt niczego nikomu z nas nie uszyje. Wymalowałem i wypisałem coś absurdalnego wodnymi farbkami na białym, gimnastycznym podkoszulku. Zaczęli się zgłaszać koledzy. - Ty, a mnie byś czegoś w ten deseń nie machnął? - Maluneczki na podkoszulkach podniosły mój prestiż...

Sumując, pierwszy Poznań, który polubiłem, to był Poznań studencki, rówieśniczy, wieloregionalny, w tym ostatnim aspekcie podobny do Szczecina. I właśnie ten Poznań miał mnie wkrótce ocalić przed bezdomnością. Po letnich wakacjach stawiłem się w domu studenckim z bagażem i zapałem do studiów na drugim roku, jednakże okazało się, że na liście lokatorów mojego nazwiska nie ma. Interweniowałem w dziekanacie. Bezskutecznie. Zawieruszyło się, przepadło. - Ja panu łóżka nie urodzę - oznajmiła kierowniczka dziekanatu, i nie dało 
się temu zaprzeczyć. Jakiś czas, może trzy, może cztery tygodnie błąkałem się po mieście, które nie miało już w sobie ubiegłorocznej metafizyki otwartego uniwersum; zaglądałem do okien, do cudzych mieszkań, do bram, które dla mnie były zamknięte. Do późnych godzin wieczornych. Poznańscy mieszczanie, dygocąc, zrzucali swe ancugi i kiereje, wskakiwali pod puchowe kołdry, a moi koledzy, tym razem z polonistyki, przemycali mnie na noc do swoich zakątków, do zasłoniętych kolorowymi parawanami fragmentów korytarzy, przykuchennych klitek, jeden zajmował... spiżarkę, w której z trudem pomieścił się tapczan... Krótko mówiąc, waletowałem. I dookoła wszystkim opowiadałem o swojej sytuacji. - Stary, szukasz chaty? zagadnął mnie na moście Teatralnym znajomy z akademickiej stołówki. - Oglądałem jedną na Górczynie. Do tramwaju dwa kroki. To plus, ale mi nie pasuje dzielenie pokoju z synem właścicieli, ten lujek raz jest, raz go nie ma, wraca z morza i wtedy mam przerąbane. Ale w twojej sytuacji lepszy pokój z chrapiącym majtkiem niż ławka w parku Sołackim. - Dwa lata na Górczynie mieszkałem, głównie nocowałem, marynarz do świtu słuchał muzyki radiowej z Luksemburga, spał do obiadu. Ani towarzyski, ani konfliktowy, coś jak „mgła nierozeznawka” z ballady Leśmiana.

Jesienią 1959 roku zamieszkałem wraz z żoną u moich teściów na Wildzie, w solidnej, secesyjnej kamienicy z 1918 roku. Tak zostałem przygarnięty przez Poznań, nieprędko, ale na długo, do dziś. W paru zaprzyjaźnionych ośrodkach literackich i literaturoznawczych jestem uważany za „typowego” poznaniaka, gdyż staram się na ogół dotrzymywać terminów i wywiązywać się z zobowiązań, choć Bogiem a prawdą zawodowej solidności nauczył mnie nie tyle Poznań, ile moja mama, traktująca pracę nauczycielską jak przywilej i posłannictwo.

B.M.W.: Czy w okresie poznańskim również można by powiedzieć, że należeli państwo do tamtejszej cyganerii? Czy w Poznaniu chodzili państwo też słuchać dżezu? Pytam o te przybytki kultury wysokiej, o których wspominała pani Bogusława, opowiadając o czasie szczecińskim.

E.B.: Słuchaliśmy koncertów dżezowych Jerzego Milana w salce teatru lalkowego „Marcinek” i w klubach studenckich. Ale tematy zawarte w tym krótkim pytaniu otwierają tak wiele zdarzeń, że trzeba je uporządkować. Przede wszystkim były dwa okresy poznańskie: studencki i nauczycielski, przedzielone rocznym pobytem w Szczecinie. W okresie studenckim nie znalazłem drogi do poznańskiej cyganerii artystycznej, już uformowanej, mocnej, dysponującej prasą („Wyboje”), sceną (kabaret Żółtodziób), dwiema grupami poetyckimi (Swantewit i Wierzbak), które pozyskiwały czytelników i przychylność władz zbiorowymi spotkaniami autorskimi i publikacjami. Znakiem firmowym młodego Poznania literackiego stał się almanach grupy Wierzbak Liść człowieka, poprzedzony wierszem, zamiast wstępu, pióra Kazimiery Iłłakowiczówny. Większość z poznańskich pisarzy, wstępujących 
do literatury po 1956 roku, wywodziła się z Koła Młodych Literatów, które się właśnie, jako relikt socrealistycznych błędów i wypaczeń, rozsypało, a właściwie zmieniło formułę istnienia. Cyganerie ówczesne w licznych miastach Polski prowadziły byt podwójny, rzec by można: nocny i dzienny. Nocny, biesiadny, alkoholowy, kultywował rytuały bohemy. Spełniał się w nieustającym karnawale. Natomiast dzienny, trzeźwy, instytucjonalny, skupiał się na organizacji oficjalnych imprez artystycznych. Rodziła się epoka grup i festiwali, rozmaitych „jesieni” i „wiosen” poetyckich, malarskich, łączących czytanie poezji z jej programowaniem i komentowaniem. Poznań wsławił się festiwalami poezji, przede wszystkim opisanym w opowiadaniu Stanisława Czycza And, wielkim ogólnopolskim festiwalem, zdobionym rozklejanymi na slupach ogłoszeniowych plakatami z atrakcyjnie pomyślanym hasłem „Poezja chlebem powszednim”. Sukcesywnie poznawałem starszych ode mnie twórców młodego, literackiego Poznania. Adam Kochanowski, związany z „Żółtodziobem”, i Józef Ratajczak, wierzbakowiec, studiowali w tamtych latach polonistykę. Ich znałem najlepiej. Ale to energiczne środowisko, już ukształtowane, z „rozdanymi” rolami, było zbyt liczne, zbyt głęboko osadzone w zbiorowej pamięci dokonań wcześniejszych, by zapraszać do siebie nas, wciąż jeszcze nastolatków. Ambitnym nastolatkom nie pozostawało zatem nic innego, jak powołać do istnienia własną cyganerię. Jej klimaty i dramaty, łączące radosne ekscesy uliczne ze arcypoważnymi „rozmowami istotnymi” w stylu Witkacego, próbowałem uchwycić w swym debiucie powieściowym Pobyt.

Żyłem w środku tego żywiołu, zatopiony w nim po czubek głowy, a ów żywioł studenckiej bohemy, stworzony w imię buntu, przeciwstawiał się, co prawda, sztuce upolitycznionej, utylitarnej, lecz nie naruszał innych norm: kultury patriarchalnej. Zagarniał wyłącznie płeć męską, a jeżeli interesowało nas partnerstwo dziewczyn, to głównie w niedolach i dolach studenckich, w potańcówkach, wycieczkach, no i w interakcjach romansowych... Inna rzecz, że koleżanki polonistki nie garnęły się do naszej grupy, nie kwapiły się do wspólnego ataku na bastiony Sztuki. Bogusława uważała nas za wyniosłych sztywniaków, a ponieważ pisała wiersze, coraz ciekawsze, coraz lepsze od niektórych „męskich” produkcji z naszego kręgu, no i byliśmy parą, zależało mi na stopniowym pozyskiwaniu jej dla naszych działań - artystycznych. Przygotowaliśmy premierę Eksperymentalnego Teatrzyku Poetyckiego Wiatraki. Był to montaż tekstów niekoniecznie naszego autorstwa. Ja przetłumaczyłem z rosyjskiego Prolog do tragedii Włodzimierza Majakowskiego, zatytułowanej Włodzimierz Majakowski, mój przyjaciel, poeta Wojtek Burtowy napisał obłędne dialogi do scenariusza „mózgu wariata na scenie” z Nienasycenia Witkacego, w ten miszmasz włączyliśmy kabaretowy minispektakl Józka Bursewicza Miasto, wpletliśmy nasze wiersze i inne zdarzenia sceniczne, z fantastycznymi postaciami, jak na przykład Lampa Alladyna, którą to Lampę (w szlafroku pożyczonym 
od swej ukochanej ciotki) zagrała Bogusia Latawiec. „Działalność” teatrzyku wygasła po jednym spektaklu. Ale od tego momentu Bogusława już była wśród nas.

B.M.W.: W Szczecinie aktywnie współtworzył pan życie kulturalne. W Poznaniu w czasie studiów należał pan do grupy Wiatraki i - jak pan pisał - wałęsał się pan po mieście jako „egzystencjalista”. Opisywał pan już między innymi pełnienie funkcji p.o. kierownika Redakcji Literackiej Wydawnictwa Poznańskiego oraz współpracę z radiem. Proszę opowiedzieć o innych okolicznościach współtworzenia życia intelektualnego Poznania od lat sześćdziesiątych XX wieku.

E. B.: Studentowi trudno było marzyć o współtworzeniu życia literackiego w Poznaniu. Sukcesem stałoby się prawo najskromniejszego udziału w tym życiu. Wiatrakom udało się, oprócz jednorazówki scenicznej, zorganizować dwa wieczory autorskie, jeden w empiku, drugi w kawiarni Wrzos, notabene podczas tego drugiego wieczoru sprzedawaliśmy egzemplarze almanachu Metafory. Bardziej skuteczna i spektakularna aktywność publiczna wymagała „przyklejenia się” do instytucji posiadającej jakieś lokum w mieście, a wspaniale, gdyby także własną prasę. Próbowaliśmy zainteresować Wiatrakami PAX, który miał swój oddział w Poznaniu, wydawał książki, w tym Teodora Parnickiego, i miał tygodnik „Kierunki” (na niezłym poziomie). Ale więź z tą instytucją oznaczałoby służbę ideologii, która nie budziła naszego entuzjazmu. Zresztą z żadną ideologią nie było nam po drodze - jako początkującym literatom, oprócz idei sztuki wolnej, wyrażającej w sposób nowatorski zawiłości świata oraz metafizyczny dramatyzm człowieczego życia. Usiłowaliśmy związać się z „Ilustrowanym Kurierem Polskim”, mającym swą filię na placu Wolności w Poznaniu, coś tam nawet udało się opublikować, trochę wierszy, razem z Wojtkiem Burtowym napisałem ostrą, zarazem nieco sztubacką odpowiedź na napaść jakiegoś frustrata na Wiatraki, wydrukowałem miniaturowy reportażyk o gdańskim Teatrze Bim-Bom, z lapidarnym sprawozdaniem z mojej rozmowy ze Zbigniewem Cybulskim (dumny z tego jestem do dziś!). Niestety, IKP był organem Stronnictwa Demokratycznego, a więc znowu strukturą ideologiczną, gorzej, polityczną. Związek Młodzieży Socjalistycznej, powstający na ruinach Związku Młodzieży Polskiej, czynił starania o zainstalowanie w Poznaniu mutacji gdańskiego tygodnika „Uwaga”, i choć nie zostałem członkiem ZMS, otrzymałem od jednego z animatorów tej organizacji „misję” podjęcia pertraktacji z kolegami z Gdańska (stąd moja podróż do Trójmiasta i wywiad z Cybulskim). Nic z tego nie wyszło. Próbowaliśmy dalej. Wiatrakowcy nawiązali kontakt z redakcją czasopisma „Zdrowie i Trzeźwość”. Ale jak poezją zniechęcać do wódki? W Pobycie bohater-narrator przysłuchuje się obradom lekarzy, zwalczających alkoholizm, żeby napisać sprawozdanie. To o mnie, sprawozdania nie napisałem. 
Najdłużej korzystaliśmy ze wsparcia świeżo po Październiku wskrzeszonego Towarzystwa Uniwersytetów Robotniczych. Ono użyczało nam swojej salki (na próby i spektakl), a my, chcą nie chcąc, poddawaliśmy się ich pracy oświatowej, polegającej na zbliżaniu młodej inteligencji, czyli nas, do trudu fizycznego robotników. Jest taka scena w Pobycie, w której grupa poetycka Cztery (Wiatraki) uczestniczy w zwiedzaniu miejskiego zakładu oczyszczania miasta. Ten powieściowy epizod ma źródło w zdarzeniach faktycznych. Gdy teraz wywołuję z pamięci wszystkie nasze wysiłki „zaistnienia” w kulturze Poznania, sam się dziwię, ile tego było i jak długo nie dawaliśmy za wygraną. Nie zraziliśmy się nawet tym, że nasz artystyczny manifest został ośmieszony w audycji lokalnej rozgłośni Polskiego Radia. Lecz szamotanina między poznańskimi instytucjami przynosiła nikłe rezultaty, narastało zmęczenie, więzi grupowe rozluźniały się, Aleksander Wojciechowski, współautor słów do Tańczących Eurydyk, śpiewanych genialnie przez Annę German, szukał szczęścia w pobliżu estrady, Witek Różański oblał egzaminy poprawkowe i został wcielony do wojska, Marian Dziurleja, samotnik, nie gustował w kolektywnych akcjach, z Wojtkiem Burtowym trzymaliśmy się razem, ale i jemu, i mnie było łatwiej przebijać się do mediów osobno. Wojtek ogłosił kilka wierszy w IKP, udało mi się zadebiutować recenzją (o Zawiści Jurija Oleszy) w poznańskim „Tygodniku Zachodnim”, umieścić dwa liryki z cyklu Wiersze Bogusławie w literackim dodatku do „Głosu Wielkopolskiego”. Było jasne, że Poznań nie chce nowej, jeszcze jednej grupy. Sporadycznie udzielał głosu nowym autorom osobnym.

Moja sytuacja w stolicy Wielkopolski zaczęła się powoli zmieniać od momentu, kiedy to - w 1960 roku - w Wydawnictwie Poznańskim, w Szczecińskiej Biblioteczce Debiutów, ukazał się mój pierwszy tomik Morze, pergamin i ty, wyróżniony na poznańskim Festiwalu Poetyckim (jeżeli wierzyć przeciekom, stało się to dzięki zdecydowanej opinii Juliana Przybosia i przy równie zdecydowanym sprzeciwie Mieczysława Jastruna, co uznałem za w pełni zgodne z moimi literackimi upodobaniami). Dotychczas zarówno w Szczecinie, jak i w Poznaniu brałem udział w zbiorowych spotkaniach autorskich. Publikacja Morza umożliwiła mi pierwszy w życiu autorski wieczór indywidualny, poprzedzony prelekcją krytyka, a właściwie historyka literatury, o którym być może będę tu miał jeszcze okazję parę słów powiedzieć, Kazimierza Bartoszyńskiego. Co równie istotne: Morze, pergamin i ty (plus wiersze ogłoszone w paru almanachach) zostało ocenione przez Komisję Kwalifikacyjną Zarządu Głównego Związku Literatów Polskich jako wystarczający argument dla przyjęcia mnie w poczet członków tej organizacji.

O rzeczywistym udziale w życiu literackim Poznania mogę mówić dopiero w odniesieniu do lat „poszczecińskich”, od jesieni 1961 roku. Miałem pewność, że w stolicy Wielkopolski osiedlam się na dłużej, w związku z czym poprosiłem o przeniesienie mnie do poznańskiego 
Oddziału ZLP. Był to oddział znacznie liczebniejszy od szczecińskiego, z przedwojennymi tradycjami, notabene w pierwszych latach po drugiej wojnie światowej uruchomiony między innymi przez mojego teścia, Czesława Latawca. Traktowany przez władze lokalne, ale i centralne, a w rezultacie przez podległe im redakcje, jako ważna instytucja. A co to wówczas znaczyło? A to, że tworzyliśmy gremium obdarzone przywilejami i obowiązkami, wspierane i podległe jawnej kontroli, łącznie z inwigilacją esbecką, oczywiście dość skutecznie utajnioną.

B.M.W.: Na czym polegały przywileje zrzeszonych pisarzy?

E. B.: Niezrzeszonych nie znałem. Po Warszawie krążyły słuchy, że podobno Stanisław Dygat pożegnał się z ZLP za uporczywe niepłacenie składek. Nie wiem, czy to prawda. W Peerelu było się albo twórcą bez książkowego dorobku, oczekującym na przyjęcie do ZLP, albo twórcą, co prawda, z dorobkiem, ale zaopiniowanym negatywnie i odesłanym do kolejki, albo - pomyślnie ocenionym przez Komisję Kwalifikacyjną i obdarzonym legitymacją związkową. Co do przywilejów socjalnych, to w niewielkim stopniu odbiegały one, choć zapewne odbiegały, od rutynowych przywilejów związkowych. Dla nielicznych - skromne stypendia, niewielkie zapomogi finansowe (ani o jedno, ani o drugie nigdy się nie ubiegałem), dalej: (odpłatne) korzystanie z domów pracy twórczej (Bogusława i ja wielokrotnie spędzaliśmy wakacyjne dni, zimowe lub letnie, w literackiej „Astorii” w Zakopanem). Dodać do tego należy możliwości poprawy warunków wykonywania zawodu pisarza. A więc prawo do samodzielnego pokoju do pracy, jako ochrona przed przymusowym dokwaterowaniem obcych lokatorów (ubiegałem się i uzyskałem „papierek” od ministra kultury), wsparcie w staraniach o domowy telefon (udało się, gdy zostałem sekretarzem Oddziału). Nie były to oszałamiające „złote góry”, zwłaszcza z dzisiejszego punktu widzenia. Przywilejem najcenniejszym, zwłaszcza w tamtych czasach, acz reglamentowanym w sposób, rzekłbym, mocno towarzyski, była możliwość udziału w pisarskich wyjazdach za granicę. Korzystali z tego głównie koleżanki i koledzy z Warszawy. Sam nigdy o to nie prosiłem. Raz o mnie, o moich rosyjsko-ukraińskich doświadczeniach i zainteresowaniach, pomyślał Egon Naganowski, członek Komisji Zagranicznej, zgłosił mnie do składu wieloosobowej delegacji ZG ZLP, wizytującej radzieckie środowiska twórcze, zwiedzającej muzea, teatry, redakcje literackie Moskwy, Kijowa i Leningradu (opisałem to w Któżby nas, takich pięknych, częściowo powtórzyłem w zbiorze Perehenia i słoneczniki). A po wielu latach Jan Maria Gisges (żartowaliśmy: Jezus Maria Gisges), sekretarz Zarządu Głównego, zaproponował mi parodniowy pobyt w deszczowej, listopadowej Sofii, w roli reprezentanta ZLP na uroczystej inauguracji Stowarzyszenia Bułgarskich Tłumaczy. Parokrotnie zabierałem głos (po rosyjsku), za każdym razem zapowiadany patetycznie: - A teraz Polska... 
Oprócz wspominanych wparć i atrakcji ZLP dawał coś jeszcze innego - jak by to określić? - rozpoznawalność! Nieodzowną zwłaszcza dla krytyka. Znalezienie się wśród członków ZLP stanowiło coś w rodzaju coming out, wyjścia z cienia, wyzwolenia się z niewidoczności.

W naszej rozmowie wspominałem już o podjętej przeze mnie pracy w Wydawnictwie Poznańskim. Warto tę opowieść uzupełnić o parę detali, gdyż ilustruje ona mechanizm zdobywania praw do uczestnictwa. Geneza wydawniczego epizodu w moim życiu zawodowym jest osobliwa. Zaczęło się od „Gazety Poznańskiej”. Jej redaktor naczelny zaproponował mi stałą współpracę recenzencką. Przynależność do ZLP nie była wystarczającym powodem tak atrakcyjnej oferty, była nim moja ówczesna aktywność krytycznoliteracka w prasie literackiej i codziennej Szczecina, Bydgoszczy, Zielonej Góry. Lecz gdybym nie należał do ZLP, pewno nie zostałbym zauważony. „Gazeta Poznańska” dawała mi pełnię swobód w zakresie stylu i wartościowania, lecz oczekiwała przede wszystkim opinii na temat twórczości autorów miejscowych. W praktyce chodziło głównie o książki Wydawnictwa Poznańskiego. Młodzieńcze zauroczenie pamfletami Karola Irzykowskiego, Tadeusza Peipera, Witkacego skłaniało mnie do oceny bieżącej produkcji literackiej wedle mocno wygórowanych kryteriów. Nie oszczędzałem słabszych publikacji oficyny poznańskiej. Jakoż pewnego słonecznego dnia w czasie dyżuru w czytelni Katedry Literatury Polskiej odebrałem telefon z Wydawnictwa Poznańskiego i usłyszałem, że dyrektor Jerzy Ziołek (nie mylmy go z Jerzym Ziomkiem!) pragnie mnie zatrudnić na stanowisku kierownika redakcji literackiej. Propozycja była kuriozalna - z uwagi na to, że nie miałem żadnych kwalifikacji ani doświadczeń wydawniczych, pomijając uniwersytecką, czysto teoretyczną wiedzę o podstawach sztuki edytorskiej. Najwyraźniej dyrektorowi chodziło o „uspokojenie” młodego Zoila, który w swych gazetowych recenzjach psuł wizerunek lokalnego wydawnictwa. Jako kierujący redakcją literacką nie mógłbym wypowiadać się o książkach swego pracodawcy ani pochwalnie, ani polemiczne. Cel oferty pachniał intrygą rodem z drugorzędnej powieści okresu międzywojennego, ale furda analogie literackie! Pokusa pracy w świecie rodzących się książek zadecydowała o mojej zgodzie. Po to jednak, by nie rezygnować z uniwersytetu, nie chciałem pełnego etatu, przyjąłem stanowisko pełniącego obowiązki kierownika redakcji literackiej. Sam sobie wyznaczyłem zadanie edukacyjne, siadałem przy biurkach pań redaktorek, zwłaszcza taktownej i mądrej Aleksandry Misterskiej, a od zamążpójścia Karskiej, obserwowałem profesjonalne decyzje, pytałem o szczegóły techniczne i uczyłem się, uczyłem, uczyłem zawodu wydawcy. Wkrótce powstał w Poznaniu miesięcznik „Nurt”, z którym współpracowałem od początku, a gdy redaktor naczelny Krzysztof Kostyrko zaproponował mi prowadzanie działu literatury polskiej, rozstałem się z wydawnictwem i zostałem jednym z redaktorów „Nurtu”. 
B.M.W.: Jak wspomina pan środowisko Związku Literatów Polskich w Poznaniu?

E.B.: Zostałem przyjęty przez nowych kolegów... umiarkowanie życzliwie i od razu „wkomponowano” mnie do jednej z frakcji konkurujących o władzę w literackim mikroświatku. Pamiętam, że gdy jechałem tramwajem na zebranie sprawozdawczo-wyborcze, spotkałem Przemysława Bystrzyckiego, który poinformował mnie konfidencjonalnie, a zarazem w sposób niezakładający sprzeciwu, że „naszym” kandydatem na prezesa Oddziału jest Tadeusz Kraszewski. Nie czytałem żadnej książki pana Tadeusza (pisał między innymi powieści historyczne dla młodzieży), nie miałem też własnego kandydata, a wiadomość, że znalazłem się wśród jakichś „nas”, w jakimś tajnym sprzysiężeniu, zaintrygowała mnie. Zagłosowałem na Kraszewskiego, został wybrany przez większość. Rówieśnik mojego ojca, z czasów polonistycznej młodości bliski kolega Czesława Latawca, okazał się prezesem wiarygodnym i prostolinijnym (tymi właściwościami, jak przekonałem się później, Wszechmogący nie obdarzył Bystrzyckiego). Od tego zdarzenia Oddział pozostawał terenem gry sprzecznych interesów grupowych, w tym także politycznych, zarówno przy kolejnych wyborach Zarządu czy delegatów na Walny Zjazd, jak i interesów indywidualnych, gdy na przykład na krótko przed powstaniem Nurtu o nasze poparcie na stanowisko naczelnego zabiegali - w czasie męczących, wielogodzinnych zebrań - Bogusław Kogut i paru innych kolegów. Skończyło się na oddelegowaniu przez KW PZPR „aparatczyka” Krzysztofa Kostyrki, który okazał się nadspodziewanie kompetentnym, pomysłowym, wysoko mierzącym animatorem poznańskiego miesięcznika.

Skład osobowy Oddziału, coraz liczniejszego, był miniaturą ówczesnej Polski. Kontrastom poetyk autorskich odpowiadały kontrasty pisarskich biografii. Poeta-tłumacz urodzony w Petersburgu, zafascynowany literaturą rosyjską (Eugeniusz Morski) i eseista-tłumacz urodzony w Innsbrucku, zafascynowany literaturą niemieckojęzyczną (Egon Naganowski). Była sekretarka Piłsudskiego (Kazimiera Iłłakowiczówna) i były, więziony przez sanacyjne władze, członek Komunistycznej Partii Polski (Tadeusz Becela). Były piewca Dywizjonu 303 (Arkady Fiedler) i były żołnierz Gwardii Ludowej, następnie uczestnik akcji Wisła w płonących Bieszczadach (Jerzy Korczak). Była współpracowniczka przedwojennego, faszyzującego Prosto z Mostu (Amelia Łączyńska) i chrześcijanin pochodzenia żydowskiego, manifestujący zarówno swój rodowód, jak i religijność (Roman Brandstaetter). Były uczestnik walk w Hiszpanii - po stronie republikanów (Bogdan Rutha) i były cichociemny (Przemysław Bystrzycki). Były żołnierz Armii Krajowej, po wojnie poseł na sejm z ramienia PZPR (Bogusław Kogut) i aktywny uczestnik walk pod gmachem UB w czasie krwawego czerwca 1956 roku (Andrzej Górny). Trzeba przyznać, choć to lista mocno niekompletna, że różnorodność polskich losów była w naszym ZLP nie mniej spektakularna niż w Popiele i diamencie Jerzego 
Andrzejewskiego. Z tą jednakże zbawienną różnicą, że nie tylko nie strzelaliśmy do siebie, ale potrafiliśmy bywać solidarni wobec innych środowisk czy urzędów.

B.M.W.: Gdy pytałam o szczecińskie autorytety czasu inicjacji literackiej, wskazał pan Witolda Wirpszę i Józefa Bursewicza. Kogo analogicznego wskazałby pan w Poznaniu w początkowym okresie mieszkania i pracowania tam?

E. B.: No więc właśnie: „autorytety czasu inicjacji literackiej”. Do listy „szczecińskiej” dodałbym Marię Kurecką i Juliusza Burskiego. Gdy go spotkałem po latach na konferencji w Lublinie i wyznałem mu, że jest dla mnie autorytetem, powiedział błagalnie: - Edward, nie rób mi tego, autorytet nie ma prawa ani się upić, ani narozrabiać, ani odezwać się głupio... Litości! - Jak już wspominałem, w pierwszych latach pobytu w Poznaniu nie miałem bezpośredniego kontaktu z pisarzami dojrzałymi. Tylko Zbigniew Pędziński, którego opinii zawdzięczam swój książkowy debiut poetycki, zainteresował się mną, zapraszał do domu, ale traktował mnie tak, jakbym to ja miał mu coś istotnego do przekazania... Wielbiłem Juliana Przybosia, który jednak był daleko, w Warszawie. Naturalna potrzeba buntu przeciw zastanym hierarchiom, charakterystyczna dla młodych, którzy się już czegoś o danej dziedzinie dowiedzieli, a ja czegoś dowiedziałem się w Szczecinie, okazała się w Poznaniu silniejsza niż pragnienie mistrza, przewodnika, rzeczoznawcy, któremu ma się ochotę zaufać bezgranicznie. Dotyczy to jednak wyłącznie kręgów wtajemniczenia w twórczość literacką. Nie dotyczy wiedzy o literaturze. Na studiach zorientowałem się, że o badaniach literackich wiem mniej niż niewiele. Jeżeli jednak tajniki biografistyki, archiwistyki, bibliografii Estreichera, dialektologii, gramatyki języka staro-cerkiewno-słowiańskiego budziły respekt, ale nie rzucały na kolana, to na drugim roku studiów, na zajęciach prowadzonych przez Kazimierza Bartoszyńskiego, dowiedziałem się o istnieniu dziedziny niezwykłej, porywającej, a mianowicie teorii literackiej formy (wedle Borysa Tomaszewskiego) i ontologii dzieła literackiego (wedle Romana Ingardena). To był prawdziwy wstrząs! Zrozumiałem, po rozczarowaniach pierwszoroczniaka, że warto było walczyć o polonistykę, żeby spotkać Bartoszyńskiego.

B.M.W.: Jakie miejsce w Poznaniu było dla pana odpowiednikiem szczecińskiego klubu $13 \mathrm{Muz}$ ?

E.B.: Studencki klub Od nowa był takim odpowiednikiem i jednocześnie nie był. Był, ponieważ w klubie Od nowa skupiało się życie poznańskich wspólnot artystycznych i intelektualnych - wszystkich pokoleń, podobnie jak w szczecińskich 13 Muzach. Nie był, ponieważ w klubie szczecińskim rzadko miałem okazję do indywidualnych publicznych wystąpień, pojawiałem się tam raczej jako słuchacz i widz, niekiedy jako uczestnik zdarzeń biesiadnych, natomiast w klubie Od nowa, począwszy od 1963 roku, regularnie prezentowałem własne 
teksty, felietony, recenzje, polemiki, parodie literackie w kolejnych edycjach czytanej gazety „Struktury”. Mieliśmy stałą publiczność, duże zaplecze autorskie, poszukiwaliśmy też urozmaiceń widowiskowych - raz urządziliśmy happening. Byłem członkiem redakcji „Struktur”, a przez jakiś czas redaktorem naczelnym.

Rozmawiamy już bardzo długo, pozwolę więc sobie wyręczyć się przypisem: o klubie Od nowa i moim uczestnictwie w życiu tej legendarnej już dzisiaj placówki piszę w jednym z esejów zamieszczonym w książce Pochwała poezji. Z pamięci, z lektury, którą Instytut Mikołowski wydał w 2013 roku. Warto - dla dopełnienia obrazu - przypomnieć wiele mówiący tytuł tego szkicu: Poznań polifoniczny (którego już nie ma).

B.M.W.: Jak pisał pan w Zuchwalstwach samoświadomości, Julian Przyboś uwierzył w grupę „Nurtu”, poniekąd widząc w nim następcę „Zwrotnicy”. Państwo zaś koncentrowali się raczej na tworzeniu czasopisma, a nie grupy poetyckiej. Proszę opowiedzieć więcej o okolicznościach współredagowania „Nurtu”.

E.B.: W okresie międzywojennym nie dostrzegano sprzeczności między grupą poetycką a kolektywem autorskim, skupionym wokół czasopisma. „Zdrój” ekspresjonistów poznańskich, „Skamander” skamandrytów, „Zwrotnica”, potem „Linia” awangardy, „Kwadryga” kwadrygantów, „Żagary” żagarystów, „Okolica Poetów” autentystów... Rzecz w tym jednak, że były to periodyki prywatne, wydawane za pieniądze autorów i sponsorów. W Polsce powojennej czasopisma były finansowane z kasy państwa, siłą rzeczy otwarte dla wielu piór, a próba przekształcenia któregokolwiek periodyku w organ jakiejś szkoły pisarskiej rodziła protesty. A jednak gdyby prześledzić poezję ogłaszaną na łamach „Nurtu” w okresach, gdy redaktorami działów poetyckich byłem ja, po mnie Stanisław Barańczak, a po nim Bogusława Latawiec, dałoby się rozpoznać w tych wierszach wyraźną estetyczną dominantę, podobnie jak w utworach, które do druku we wrocławskiej „Odrze” kwalifikował Tymoteusz Karpowicz. Samo zaś współredagowanie „Nurtu” polegało na autonomii redaktorów poszczególnych działów, co prawda, Kostyrko regularnie zwoływał posiedzenia zespołu redakcyjnego, nieraz także w rozmowach w cztery oczy wygłaszał długie, dość skomplikowane językowo monologi, rysujące wizje przyszłościowe, to jednak w praktyce pilnował głównie strony ideologicznej, jako historyk sztuki - dbał o stronę plastyczną, a jeżeli interweniował w inne działy, to wyłącznie wtedy, gdy za nasze decyzje czy ekstrawagancje dostawał burę na partyjnym „dywaniku”. 